Original Research Paper

\title{
Creating a Link between HR Department and Budgeting: What do HR Managers Think?
}

\author{
${ }^{1}$ Sibtain Kazmi, ${ }^{1}$ SAF Hasnu and ${ }^{2}$ Raja Ahmed Jamil \\ ${ }^{I}$ COMSATS Institute of Information Technology, Abbottabad, Pakistan \\ ${ }^{2}$ Department of Management Sciences, University of Haripur, Pakistan
}

\author{
Article history \\ Received: 6-01-2015 \\ Revised: 3-02-2015 \\ Accepted: 27-05-2015 \\ Corresponding Author: \\ Raja Ahmed Jamil \\ Department of Management \\ Sciences, \\ University of Haripur, Pakistan, \\ Tel: +923008118557 \\ Email: raja.ahmed@uoh.edu.pk
}

\begin{abstract}
This research endeavours to investigate the involvement of the Human Resources (HR) department throughout the budgeting process and the utilization of budgets to further perform HR activities. Study seeks empirical evidence based on the responses elicited from HR department managers in 100 Pakistani companies with a distinct HR department. Results suggest that the HR department has limited involvement in the budgeting procedures, which in turn could explain the limited use of budgets as a means of performance evaluation and communication. Evidence from survey showed that HR departments in Pakistan do fully capitalize on the budgets as a mean of achieving organizational goals. This study contributes to the literature by analysing the responses of HR department managers and their views towards the budgeting function from HR management perspective in Pakistani companies.
\end{abstract}

Keywords: Budgeting, Human Resources, Department, Motivation, Communication, Performance Evaluation, Control, Pakistan

\section{Introduction}

Budgets quantify organizational plans over a given time period and are used to check and control the progress of an organization so that it keeps its movement within the established boundaries (Searfoss and Monczka, 1973). They represent the financial goals of an organization.

Cohen and Karatzimas (2011) noted that budgets go beyond performing the function of planning and controlling for management. Budgets provide a tool that could benefit an organization in developing coordination among its various parts, to measure employees' performance and control them, to motivate personnel and to enhance communication (Fisher et al., 2002; Yuen, 2004; Hansen and van der Stede, 2004; Parker and Kyj, 2006). Human resources department, generally thought of as having duties such as recruitment and selection, training and development, pensions and the like, is also liable for performance related bonuses, information flow and employees' motivation (Cohen and Karatzimas, 2011). Thus, there exists a relationship between budgeting and the HR department. The degree to which HR department is involved in the preparation and implementation of budgets could increase the effectiveness of the aforesaid budgeting characteristics. Nonetheless, analysing budgeting process from the perspective of Human Resource Department is not common in the literature (Cohen and Karatzimas, 2011). There has only been a limited number of studies related to HR management- management accounting interface from an HR viewpoint (Berry and Bacon, 2002; Stiles and Kulvisaechana, 2003; Bacon and Berry, 2005; Kouhy et al. (2009). These studies imply the mind-set of HR managers and management accountants who justify the HR initiatives on financial aspects (Cohen and Karatzimas, 2011).

The study undertaken has a two-faceted scope. On one hand, it determines the role of HR department in budget preparation and its implementation; since in Pakistani business environment, the role of HR department is quite unarticulated. On the other hand, it investigates the interaction between budgeting process and certain management functions performed by the HR department. Budgeting encompasses several functions that are linked with HR management such as employees' motivation, performance evaluation, internal communication and control. This study strives for finding if the HR departments in Pakistani organizations actually exploit the opportunities offered through budget preparation and implementation. To be more specific, this study asks several questions to the HR managers related to the extent to which Pakistani organizations use the budget-related compensations and the level of difficulty for achieving the budgetary goals so that the 
employees and the managers get motivated, the use of budgets as a means of information flow-both horizontal and vertical, if budgets are used as a mechanism for measuring performance as well as the influence of budgetary control on the behaviour of the employees.

Besides these functions which are to be performed by this study, it also investigates the impact of the involvement of HR in budgeting on different variables. These variables include control, motivation, communication and performance evaluation. Hence, this study has multi-functions. On one hand, it provides us with some statistics regarding the HR department's role in budgeting in Pakistani organizations. And on the other hand, it investigates a model in which the impact of the role of HR in budgeting is tested on variables of interest.

The rest of the paper is organized as follows. In the second section, the relevant literature is reviewed. In the third section, the survey's methodology is analysed, while in the fourth section, one the empirical results are presented. Finally, the paper concludes with a discussion of the findings.

\section{Literature Review}

Several studies have been undertaken analysing the relationship that exists between budgeting and employees' motivation, internal information flow, performance evaluation and control (Merchant and van der Stede, 2003; Marginson and Ogden, 2005; Kominis and Emmanuel, 2007; Byrne and Damon, 2008). In the lines following, the empirical evidence related to the relation between budgeting and the aforesaid dimensions. Moreover, some findings of a few studies are also presented that have analysed association between management accounting and HR management through the eyes of the HR management.

\section{Motivation}

Cohen and Karatzimas (2011) consider two factors to be the most important in order to study the impact of budgeting procedures on motivation: First, the interaction between meeting budgetary goals and the reward system of the organization and the second, the level of difficulty posed through budgetary goals.

\section{Motivation by using Rewards}

Budget procedures lead to motivation when they are associated with employees' performance evaluation and the reward system being offered by the organization (Hofstede, 1968). This implies that budgets are perceived as targets by employees to achieve so that they can win promotions and bonuses (Cohen and Karatzimas, 2011). Since, the achievement of the expected performance is associated with standard rewards, employees are anticipated to put extra efforts to meet their goals, which ultimately will result in increased performance and productivity (Merchant and van der Stede, 2003; Reid, 2002). It is a common practice among senior management to increase managers' and employees' performance by promising rewards on the achievement of the desired results.

Rewards have been distinguished into two types by Deci (1971; 1972); first, intrinsic rewards and second, extrinsic rewards. Intrinsic rewards are the ones that come from the inside, for instance, the satisfaction that results due to achievement of some goal or an assignment. On the other hand, extrinsic rewards consist of acknowledgement, prizes and performance-centred payment. Furthermore, the latter refer to the financial and non-financial rewards. Financial rewards include bonuses, participation in the profit and commissions, etc., while non-financial rewards encompass promotions, plaudits and recognition, etc. Majority of the research studies that analyzed motivation have focused on extrinsic rewards, although a lot of researchers give more importance to intrinsic motivation (Dermer, 1975; Kaplan, 1998; Kominis and Emmanuel, 2007) and perceive it as being stronger. The reason why there is this lack of harmony is that financial rewards for superior performance sometimes have an adverse effectopposite to that which in intended (Deci, 1972). People may perceive themselves as doing work for the sake of money, which will eventually reduce their motivation for work. Often, it is more fruitful to associate budget achievement to intrinsic motivation, rather than trying to improve employees' performance through the use of financial rewards (Cohen and Karatzimas, 2011).

What is it then that does ultimately leads to employees' motivation to achieve the goals set through budget? What would be the most beneficial for the top management: To associate budgetary goals to financial or non-financial rewards? Some authors have agreed that the basic principles of expectancy theory could be used to complete the conclusions that arise from researches regarding budgeting and the motivational behaviour of employees toward rewards (Ronen and Livingstone, 1975). Kominis and Emmanuel (2007) made use of an extended version of the expectancy theory. They conducted a survey of 200 middle managers who were working in large financial service company. Their study concluded that both extrinsic as well as intrinsic rewards have a significant positive effect on employees' motivation. Besides, Emmanuel et al. (2008) also conducted a study in Greece which supported this previous study.

\section{Motivation through the use of Level of Difficulty of Budgetary Goals}

Budgets provide an obvious means of setting specific, clear and measureable targets for employees 
(Lyne, 1988). Nonetheless, the magnitude of difficulty of budgetary goals encompasses an imperative motivational aspect as well (Cohen and Karatzimas, 2011). Budgetary goals level of difficulty is a double edged sword; while effortlessly achievable goals seem to be posing no challenge for the mangers and, hence, bear little motivational impact. On the other hand, too difficult goals-the ones almost unattainable-may result in feelings of disappointment and low self-esteem (Becker and Green, 1962; Dunbar, 1971). Expectancy theory implies that if the target is expected to be too difficult, then it would have very low motivation for the employees irrespective of the rewards associated with the achievement of the target. Ronen and Livingstone (1975) stated that the fundamental belief of the expectancy theory is that people select their behaviours on the depending on their expectations that the behaviour will lead to a certain outcome. Reid (2002) concluded that the level of difficulty has an effect on employees' expectations regarding the achievement of the budget. A study was conducted by Kenis (1979) in 16 manufacturing companies. He concluded that in order to gain motivation of the manager more efficiently, budgetary goals should pose a challenge difficult enough but meanwhile achievable.

However, Kominis and Emmanuel (2007) argue that the often-cited goal characterisation of "difficult but attainable" may not lead to motivation of all managers. The results of this study support a research conducted by Stedry (1967). He stated that, under specific situations, employees' performance could be enhanced if they are imposed with unattainable goals. Stedry also found that the levels at which standards were set affected the aspiration levels of the subjects. Moreover, it was stated that respondents adjusted their aspiration level (in the direction of the level of performance that was in reality accomplished) if performance was found to be having larger differences from the level aspired. Hence, he concluded that it is advisable for the management to change the standards from time to time so that they are achievable some of the time and are marginally beyond the level that is attainable. Yuen (2004) in his research on 108 hotel managers mentioned that difficult goal circumstances can be resolved under clear reward systems. Marginson and Ogden (2005) also found a powerful impact of budgetary goals on the behaviour of the managers.

\section{Communication}

It goes without saying that budget procedures generate substantial information flows within an organization (Cohen and Karatzimas, 2011). Research on this topic started back in 1976 when Hopwood (1972) studied the impact of budget participation on communication. Parker (1978) also conducted research on the same topic. From these initial researches until present, it has been indicated that participation in the budget leads to the formation of such an environment in which exchange and utilization of organizational information is encouraged and which results in improved performance, as the subordinate's knowledge and experience will be transmitted to the supervisors, commitment will be elevated and controlled information flow will be reinforced (Chenhall and Brownell, 1988; Walker and Johnson, 1999; Clinton and Hunton, 2001). Communication types consist of upward and downward communication as well as horizontal communication.

\section{Upward and Downward Communication}

The budgeting process can be utilized in gathering subordinates' knowledge and personal information related to deliberate uncertainties the organization faces, i.e. circumstances that might pose a threat for the current strategy of an organization, such as certain moves undertaken by the competitor, shift in consumers' preferences, variations in technology, etc. (Simons, 1995). Moreover, Nouri and Parker (1998) anticipated that the quality of information discovered will add to the preparation of more accurate and realistic budgets. Budgeting process serves two purposes in terms of communication. On one hand, it provides subordinates with information regarding what their management expects from them (Ronen and Livingstone, 1975), meanwhile, it also provides feedback concerning the degree to which targets set by the budget are actually materialized (Cohen and Karatzimas, 2011). In those situations where subordinates are unaware of the consequences of their efforts, it is quite difficult for them to have feelings of success or failure and, as a result, do not feel any motivation in order to improve their performance (Becker and Green, 1962; Fisher, 1995; Henri, 2006). The greater the extent to which employees and middle managers participate in the preparation of budget, the better communication is realized and the more accurate information for the seniors to use during the formulation of the budget is assembled. For this reason, budget preparation activities along with the activities carried out for the analysis of the budget variances lead to reduction in information asymmetry (Emsley, 2001). A survey performed by Parker and Kyj (2006) depicted that vertical (upward and downward) information flow during the preparation of budget has an important role in organization commitment and performance.

Searfoss and Monczka (1973) concluded that communication also leads to enhanced participation which in turn supports one of the basic tenets of modern organization theory which states that involvement in the decision-making and goal-setting pro-cesses will result in a greater personal commitment to the organization and 
its goals. This personal commitment will, in turn, increase the level of motivation of the employee to strive toward achieving these goals.

\section{Horizontal Communication}

Brownell (1982) stated that through participation in budget preparation, the synchronization and collaboration of apparently independent departments is accomplished. This coordination and cooperation is indispensible for the organization to perform efficiently. All the information and practices regarding fresh and enhanced ways of carrying out certain activities in the business are channelled throughout the organization, which makes it possible for the employees to enhance their knowledge, learn and utilize novel techniques in their work and let their fellow employees know (Shields and Young, 1993). It is evidence in Bremser's (1988) research findings that the process of budgeting serves as a means of providing synchronized planning amongst different functional areas within an organization.

\section{Performance}

Joshi et al. (2003) in their research stated: "Budgets are financial blueprints that quantify a firm's plans for a future period". This implies that budgets act as a standard compared to which actual performance can be measured and evaluated. As budgets depict the anticipated future picture of an organization, they serve as a means of control and performance evaluation for the managers (Searfoss and Monczka, 1973). The reason being if managers and employees are aware of its substances, there would be a yearly decrease in the deviations since they would be better able to make the required amendments and decisions to achieve the expected outcomes. Hence, achieving the budget becomes an imperative goal in itself, reason being that major part of the evaluation of the employees will depend on the variance that would exist among the budget and the actual results (Searfoss and Monczka, 1973; Guilding et al., 1998; Blansfield, 2002; Fisher et al., 2002).

\section{Budgets Serving as the Major System of Performance Evaluation}

Performance is a major construct in the field of human resources (Viswesvaran, 2011). Cohen and Karatzimas (2011) stated that budgets intend to compel subordinates to enhance their performance when they are used for measuring employees' performance. This serves as an explanation to the fact behind why evaluation is associated with reward systems. Due to its employees' compensation and promotion is dependent on their evaluation (Lau and Buckland, 2001). Merchant (1998) stated that budget-emphasized evaluation style is used by the top management because it is relatively objective. According to a research carried out by Otley (1978), those companies which lay greater emphasis on budget have the luxury to enjoy results closer to their desired goals. This emphasis on the budget highlights the importance of budgetary goals and their association with the rewards offered to the employees. A number of other researches carried all over the world (Anderson, 1993; Douglas, 1994; Guilding et al., 1998) have concluded that the formulation of budget is used as the major system of performance evaluation.

\section{Level of Clarity of the Budgetary Goal}

Cohen and Karatzimas (2011) stated that besides the above stated performance related budgetary factors another important factor is the level of clarity of the goals set in the budget. Performance of the employees is enhanced when they are given some clear targets compared to those targets that are unclear. Locke and Schweiger (1979) stated that goals which are unclear to the employees may lead to employees' dissatisfaction, mental stress and frustration. It is a common practice among employees that they use budgetary slack when they are facing unclear targets. Comparatively, Yuen (2004) stated that clear targets are less likely to create budgetary slack.

\section{Control}

The very basic purpose of budgeting was to use it as an instrument for control function in an organizationcontrol over the employees and administration by limiting their spending authority (Becker and Green, 1962). The control function is usually a feedback mechanism whereby management is provided with the information (both anticipated and actual) so that they can use this for decision making (Ronen and Livingstone, 1975). It is quite evident from several researches that tight budgetary control enables management to be more systematic and through it managers also enjoy the opportunity of refining their future planning (van der Stede, 2001; Wijewardena and de Zoysa, 2001). From this standpoint, budgeting tends to become a fundamental form of control in an organization, because management becomes able to control the whole procedure by having a comparison of the results with the anticipated values and show involvement only when required. When employees are offered to have a control over their destiny, it is likely for them to exhibit higher levels of job satisfaction and increased level of performance (Brownell, 1982; Otley, 2006).

\section{Research Design and Data Collection}

This study aims at both analysing the involvement of the HR department in the budgeting process and investigating the interaction between the budgeting process and those specific management functions performed by the HR department. Besides, it also 
investigates the role of budgeting to serve as a means of achieving several functions performed by the HR departments. The organizations selected to carry out this study were chosen to be service based organizations of Pakistan. The reason behind this selection was the fact that separate HR departments are mostly found in organizations that render services. The sectors included were banks, telecommunication, hospitals, educational institutions, NGO's, insurance companies and courier services. The HR department was selected for two reasons. First, because we are interested in explicitly documenting HR departments' roles within budgeting procedures and second because we would like to assess whether Pakistani companies make use of budgeting as a means to implement significant HR functions. These functions are personnel motivation, internal communication, performance evaluation and control. Therefore, we addressed our questionnaire to HR managers on the grounds that we consider them to be the most appropriate source of information for the study.

An objective data collection method was used for this model. A self-administered questionnaire was adopted from Cohen and Karatzimas (2011) study and modified to measure the model under investigation. Each variable (HR involvement in budgeting, control, communication, performance evaluation and motivation) was measured using multiple items. A five point Likert scale was used to measure the constructs with 1 representing strongly disagree and 5 representing strongly agree.

The questionnaire comprised of a total of 22 questions. Out of which, first seven questions were included for descriptive part of the analysis. Next 15 questions were included to measure the extent to which HR department involvement in budgeting, control, motivation, performance evaluation and communication. All questions employ a Likert-scale.

\section{Sample Characteristics}

For the purpose of detecting the general relation that exists between HR-department and budgeting procedures, we included questions that were asked to know if HR departments participate in the development and implementation of the budgets. It was found from the hundred and ninety four companies included in the sample that only in 76 companies there is a practice of involving the HR department in the budgeting preparation. While in the remaining 118 companies, HR department is not given a chance in the development of the budgets. Hence, in the service sector of Pakistani organizations, $39 \%$ of the companies, HR department is considered to be a part of the budget compiling process, while in the remaining $60 \%$, it is not.
However, the results were almost the opposite for the implementation part of the budgeting. In 81 companies the HR department does not involve in the execution of the budgets, while in the rest 113 companies HR is involved in the implementation phase of the budgets. Thus, in $42 \%$ of the companies in the service sector of Pakistan HR is a part of the implementation process of the budgets, while in the remaining $58 \%$, it is not.

In Table 1, the cross tabulation between the HR departments' participation level during budget preparation and implementation is presented. The results provide corroborative evidence that firms choose whether to allow or not the department's participation in both budget development and implementation.

\section{Motivation}

Employee motivation is greatly influenced by the financial and non-financial rewards that are linked to the achievement of the results. In case of achieving the budgetary target, we asked whether and to what extent, financial or non-financial rewards are provided. First, evidence showed that $19 \%$ of the sample companies do not provide any type of financial rewards to employees for meeting their budgetary targets, while the $27 \%$ of the sample companies do not provide any form of nonfinancial rewards. Second, in $27 \%$ of the studied companies, a manager could be laid off in case he/she did not reach the budgetary targets to a satisfactory level.

Furthermore, the companies that provide rewards for meeting budgetary goals were asked to specify the type of financial or non-financial rewards they offer. Their responses are shown in the Table 2.

It turned out that the most widely used reward type is the "bonus" reward, issued by $85 \%$ of the companies" sample and a further $4 \%$ of companies provide employees with "stock options"". It should be mentioned that several companies use combinations of the above types of rewards.

As for non-financial rewards, the most commonly used type is "plaudits and recognition" which is offered by a $52 \%$ of the sample, while a $24 \%$ reward employees by providing "promotions" and a $14 \%$ provide "travel gifts-use of company car". As in the case of financial rewards, non-financial rewards in several companies are provided in combination.

\section{Communication}

Budgets are also supposed to create and facilitate internal communication (Simons, 1995; Emsley, 2001; Parker and Kyj, 2006). We analysed whether our sample organizations take advantage of this budget characteristic in order to receive more realistic information and to develop cooperation and coordination among departments. 
Table 1. Cross tabulation between the participation of HR department during budget preparation and implementation

\begin{tabular}{|c|c|c|c|c|}
\hline & \multicolumn{4}{|c|}{ HR department participate during budget implementation } \\
\hline & & No & Yes & Total \\
\hline \multirow[t]{2}{*}{ HR department participate during budget setting } & No & 71 & 47 & 118 \\
\hline & Yes & 10 & 66 & 76 \\
\hline Total & & 81 & 113 & 194 \\
\hline
\end{tabular}

Table 2. Functions that derive from the budget procedure

\begin{tabular}{lccllllll}
\hline & 1 & 2 & 3 & 4 & 5 & Total & Mean \\
& $(\%)$ & $(\%)$ & $(\%)$ & $(\%)$ & $(\%)$ & Value & SD \\
\hline Control & 9 & 13 & 40 & 28 & 10 & 100 & 3.29 & 1.089 \\
Communication & 9 & 17 & 38 & 24 & 12 & 100 & 3.17 & 1.183 \\
Motivation & 11 & 23 & 35 & 27 & 4 & 100 & 3.05 & 1.078 \\
Performance Evaluation & 8 & 9 & 33 & 31 & 19 & 100 & 3.11 & 1.176 \\
\hline
\end{tabular}

Note: 1-5 Likert-scale (1, very small significance; 5, great significance)

Table 3. Rewarding type used by the sample organizations

\begin{tabular}{lll}
\hline & Yes n(\%) & No n(\%) \\
\hline Financial rewards & & \\
Bonus & 85 & 15 \\
Stock options & 4 & 96 \\
Non-financial rewards & & \\
Promotion & 24 & 76 \\
Plaudits-recognition & 52 & 48 \\
Travel gift-company car & 14 & 86 \\
\hline
\end{tabular}

From the empirical findings, it can be seen that in $39 \%$ of the sample companies, employees and management are often involved in discussions concerning their budgetary goals during the budget setting. Moreover, the HR managers perceive the vertical communication, both "upward communication" and "downward communication" that is created by the budget processes as moderately important (mean $=3.49$ and 3.42 respectively), while the horizontal communication (coordination among departments) is considered to be less important both during "budget preparation" (mean = 3.01 ) and "budget implementation" (mean = 3.10) as shown in Table 3.

Another very important communication factor that is vital for the smooth function of an organization is the level of feedback provided concerning the employees' performance. In $71 \%$ of the sample companies, it was evident that the company provides employees with a satisfactory level of feedback, in relation to their efforts to meet budgetary goals. Nevertheless, there is a further $26 \%$ that state that the feedback provided is limited.

\section{Performance Evaluation}

The budget is considered to be a vital tool in the hands of management that can be effectively used in performance evaluation (Merchant, 1998; Lau and Buckland, 2001; Joshi et al., 2003). The HR managers were asked to rate the level in which several performance criteria are taken into consideration during the employees' performance evaluation. These criteria are: "quality of work"; "quantity of work"; "meeting deadlines"; "personal development"; "meeting the budget" and "development of new ideas". The purpose of these questions was to assess whether the level of budget achievement is regarded as a performance evaluation instrument. The results are depicted in Table 3. It is clear from the responses that "Quality of work" is considered to be the most important performance criterion while the least important one is that of "Personal development". Nevertheless, "Personal development" attained a mean value well above the average value of 3 . These answers indicate that performance assessment is a multifaceted issue that takes into account both quantitative and qualitative aspects. Therefore, meeting the budget is an important parameter albeit not the only or the primary one.

In addition, we asked questions that intended to evaluate how the attainability of the level of budgetary goals affects employees' performance. We asked the HR managers to rate the importance of several factors that are expected to increase or decrease performance. Table 5 and 6 show useful insights.

As for the factors that affect performance positively, results showed that the most important one is the "Adequacy of human and material resources" (mean = 3.68 ), while the "attainability of the budgetary targets" is considered to be of high importance too (mean = 3.12). Regarding the factors that affect performance negatively, the "inadequate personnel training and development" is considered to be the most important (mean = 3.42), while the "difficulty of the budgetary targets" is considered to be the least important factor for decreased performance $($ mean $=2.93)$. These results are found to be exactly in line with the results of the study conducted by Cohen and Karatzimas (2011). 
Sibtain Kazmi et al. / American Journal of Economics and Business Administration 2015, 7 (1): 48.59 DOI: 10.3844/ajebasp.2015.48.59

Table 4. Communication variables

\begin{tabular}{llcllllll}
\hline & $1(\%)$ & $2(\%)$ & $3(\%)$ & $4(\%)$ & $5(\%)$ & Total (\%) & Mean value & SD \\
\hline $\begin{array}{l}\text { Upward communication } \\
\text { during budgeting process }\end{array}$ & 1 & 3 & 51 & 30 & 15 & 100 & 3.49 & 0.048 \\
$\begin{array}{l}\text { Downward communication } \\
\text { during budgeting process }\end{array}$ & 2 & 5 & 48 & 31 & 14 & 100 & 3.42 & 0.053 \\
$\begin{array}{l}\text { Horizontal communication } \\
\text { during budgeting setting }\end{array}$ & 2 & 10 & 39 & 30 & 19 & 100 & 3.01 & 0.312 \\
$\begin{array}{l}\text { Horizontal communication } \\
\text { during budgeting implementation }\end{array}$ & 7 & 8 & 40 & 20 & 25 & 100 & 3.10 & 0.527 \\
\hline
\end{tabular}

Note: 1-5 Likert-scale (1, very small significance; 5, great significance)

Table 5. Performance evaluation criteria

\begin{tabular}{|c|c|c|c|c|c|c|c|c|}
\hline & $1(\%)$ & $2(\%)$ & $3(\%)$ & $4(\%)$ & $5(\%)$ & Total (\%) & Mean value & SD \\
\hline Quality of work & 1 & 3 & 15 & 51 & 30 & 100 & 4.31 & 0.539 \\
\hline Quantity of work & 2 & 5 & 31 & 48 & 14 & 100 & 3.82 & 0.741 \\
\hline Meeting deadlines & 2 & 4 & 19 & 45 & 30 & 100 & 3.87 & 0.835 \\
\hline Personal development & 1 & 7 & 21 & 46 & 25 & 100 & 3.65 & 0.824 \\
\hline Meeting the budget & 3 & 3 & 37 & 37 & 20 & 100 & 3.72 & 0.848 \\
\hline Development of new ideas & 0 & 2 & 20 & 41 & 37 & 100 & 3.99 & 0.482 \\
\hline
\end{tabular}

Note: 1-5 Likert-scale (1, very small significance; 5 , great significance)

Table 6. Factors affecting performance

\begin{tabular}{|c|c|c|c|c|c|c|c|c|}
\hline & $1(\%)$ & $2(\%)$ & $3(\%)$ & $4(\%)$ & $5(\%)$ & Total (\%) & Mean value & SD \\
\hline Factors affecting positively & & & & & & & & \\
\hline $\begin{array}{l}\text { Attainability of } \\
\text { budgetary targets }\end{array}$ & 8 & 13 & 47 & 28 & 4 & 100 & 3.12 & 0.043 \\
\hline $\begin{array}{l}\text { Adequate personnel's } \\
\text { training and development }\end{array}$ & 14 & 18 & 30 & 33 & 5 & 100 & 3.09 & 0.019 \\
\hline $\begin{array}{l}\text { Adequacy of human and } \\
\text { material resources }\end{array}$ & 8 & 14 & 41 & 28 & 9 & 100 & 3.68 & 0.002 \\
\hline $\begin{array}{l}\text { Other external factors } \\
\text { Factors affecting negatively }\end{array}$ & 10 & 16 & 37 & 24 & 13 & 100 & 3.01 & 0.084 \\
\hline $\begin{array}{l}\text { Difficulty of } \\
\text { budgetary targets }\end{array}$ & 15 & 24 & 38 & 13 & 10 & 100 & 2.93 & 0.148 \\
\hline $\begin{array}{l}\text { Inadequate training } \\
\text { and development }\end{array}$ & 11 & 9 & 28 & 34 & 18 & 100 & 3.42 & 0.487 \\
\hline $\begin{array}{l}\text { Inadequacy of human } \\
\text { and material resources }\end{array}$ & 11 & 18 & 36 & 22 & 13 & 100 & 3.13 & 0.815 \\
\hline Other external factors & 19 & 24 & 41 & 12 & 4 & 100 & 2.98 & 0.581 \\
\hline
\end{tabular}

Note: 1-5 Likert-scale (1, very small significance; 5 , great significance)

Table 7. Budgetary control

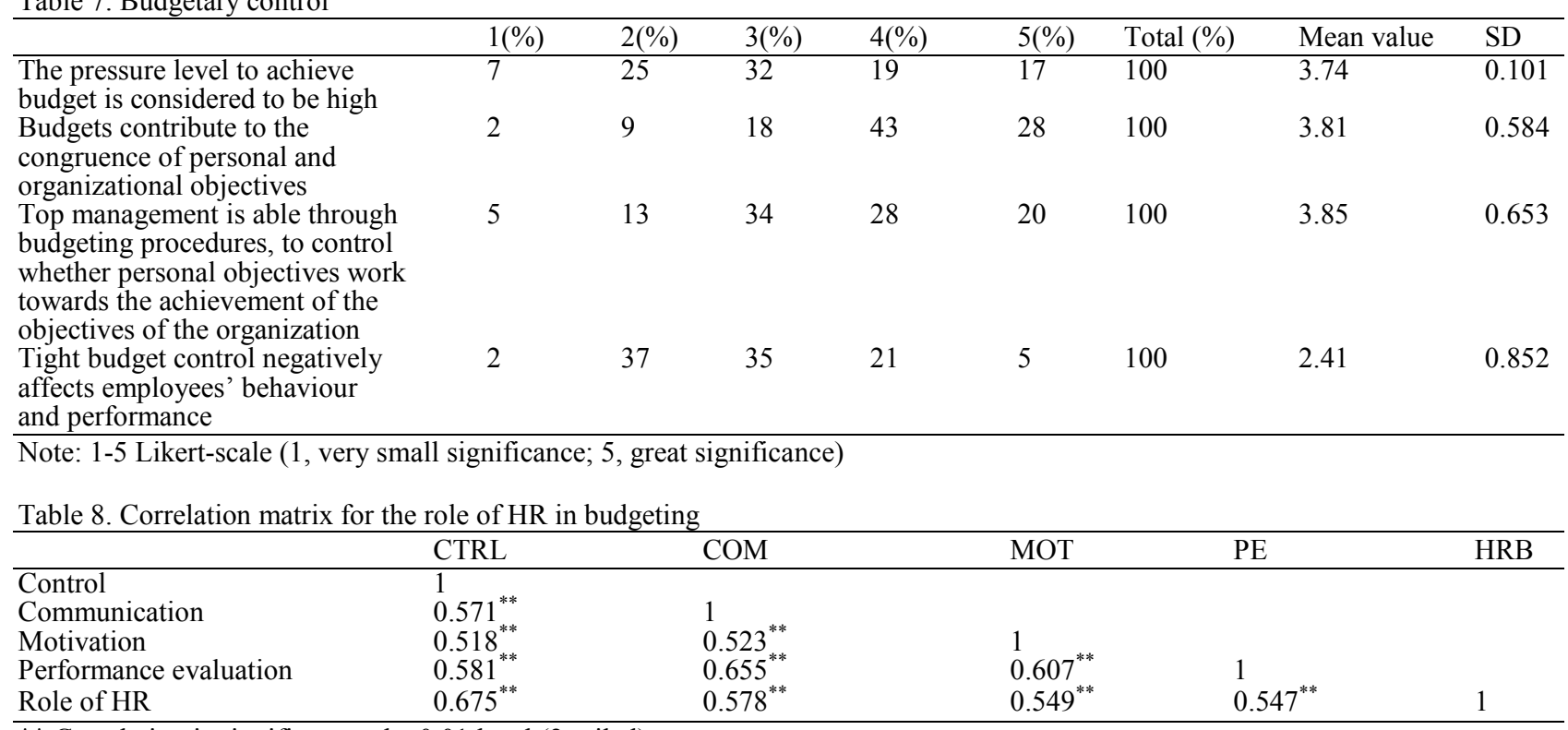

** Correlation is significant at the 0.01 level (2-tailed) 
Table 9. Results for the variables

\begin{tabular}{lllllll}
\hline Hypothesis & $\begin{array}{l}\text { Independent } \\
\text { variable }\end{array}$ & $\begin{array}{l}\text { Dependent } \\
\text { variable }\end{array}$ & Estimate & SE & CR & p-value \\
\hline H1 & HRB & CTRL & 1.265 & 0.158 & 8.016 & $* * *$ \\
H2 & HRB & PE & 1.029 & 0.121 & 8.526 & $* * *$ \\
H3 & HRB & MOT & 0.944 & 0.147 & 6.431 & $* * *$ \\
H4 & HRB & COM & 1.057 & 0.109 & 9.715 & $* * *$ \\
\hline
\end{tabular}

***Significant at the 0.001 level

Table 10. Summary of hypotheses testing

\begin{tabular}{lll}
\hline & Hypotheses & Results \\
\hline H1 & There is a positive relationship between HR involvement in budgeting and control. & Accepted \\
H2 & There is a positive relationship between HR involvement in budgeting and employees' performance evaluation. & Accepted \\
H3 & There is a positive relationship between HR involvement in budgeting and employees' motivation. & Accepted \\
H4 & There is a positive relationship between HR involvement in budgeting and communication within organizations. & Accepted \\
\hline
\end{tabular}

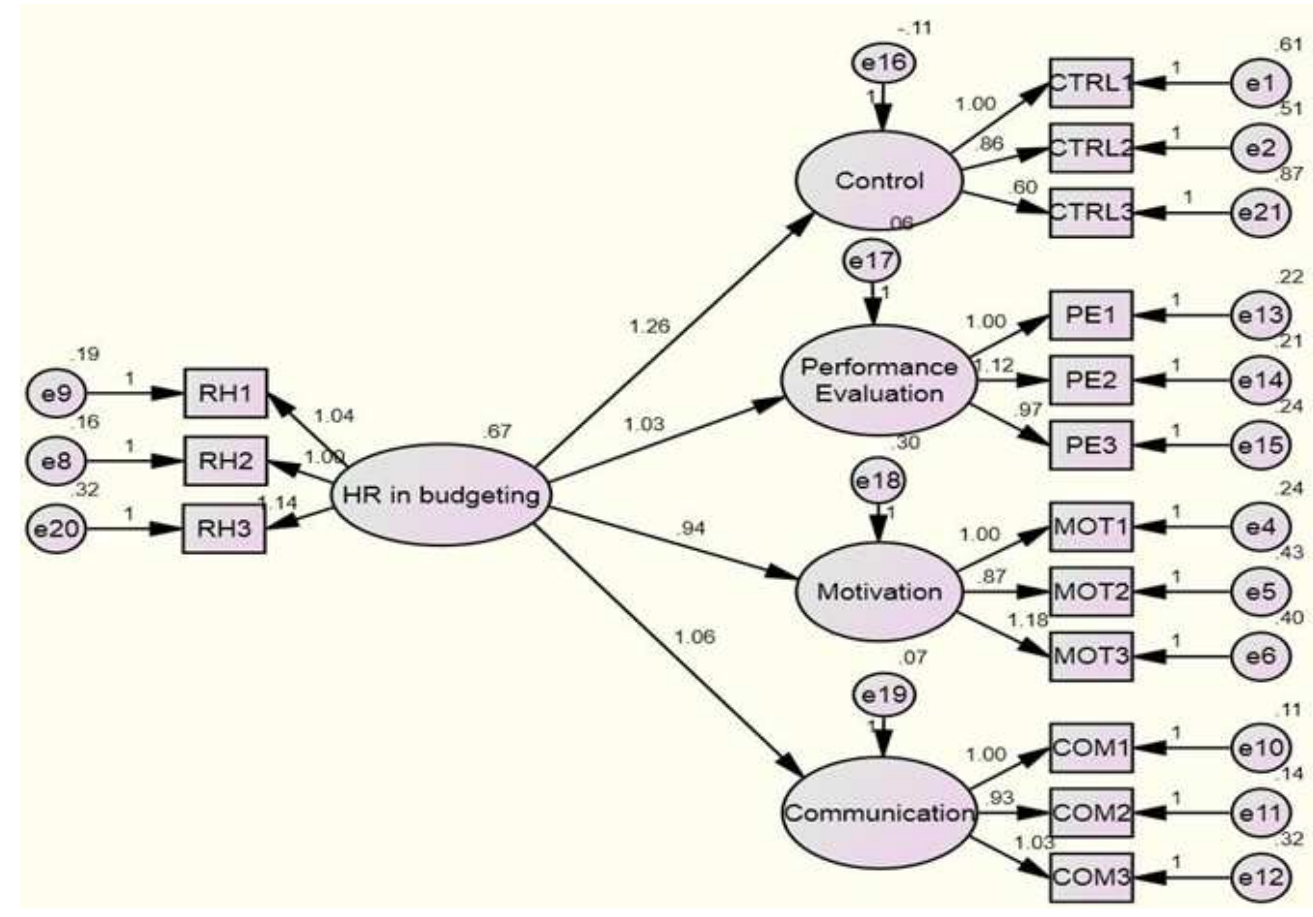

Fig. 1. AMOS output for the role of HR in budgeting

\section{Control}

Budgets also offer a way to control the organization's development in order to keep it within the desired parameters. However, it has been evidenced (van der Stede, 2001; Bisbe and Otley, 2004) that pressure to achieve the budget might lead to results opposite to those that are intended. Consequently, we tried to detect the pressure level in the companies of our sample, by asking the HR managers to rate it. The responses showed that the pressure level to achieve budget is considered to be adequately high.

In general, budgetary control is considered to offer congruence between the personal goals of the managers and the organizational goals and also to offer the opportunity to detect if this desired outcome is realized. However, tight budgetary control could also lead to dysfunctional employee behaviour. We proceeded by asking the managers to rate their agreement or disagreement on the statements reported in Table 4.

From the responses, it was very apparent that HR managers believe that budgets contribute to the congruence of personal and organizational objectives and that top management is able, through the budgetary process, to control whether personal objectives work towards the achievement of the objectives of the organization. However, contrary to what expected, they do not share the opinion that tight budgetary control negatively affects employees' behaviour and performance. 


\section{Correlation Analysis}

The strength and direction of relationships among the all the variables under investigation was calculated using Pearson product-moment correlation coefficient.

Table 1 presents the relationships among the variables under the investigation. The correlations were significant, strongly correlated and showed the positive directions. All the variables show significant relationship with each other.

This Table 8 shows that independent variable (role of HR in budgeting) had a moderate positive correlation with control, communication and motivation. However, a strong correlation was found with performance evaluation (0.616).

\section{Structural Equations Modelling}

For data analysis, AMOS, a structural equations modelling program is used to test the model shown in Table 9. The goodness of fit indexes for data collected for study shows that overall model has a good fit of the data.

The results of hypotheses tested in the study are presented in Table 3 and the coefficients that indicate the direct influence of independent variables on dependent variables are shown in Figure 1. Out of five paths in the proposed model, all were found to be statistically significant.

These paths show that impact of $\mathrm{HR}$ role in Budgeting (HRB) is significant on control (CTRL). HR role in Budgeting (HRB) was found to be the significant predictor of Communication (COM), Motivation (MOT) and Performance Evaluation (PE).

\section{AMOS Output for the Role of HR in Budgeting}

Figure 1 illustrates the results of this study. The highest regression estimate (1.26) was found between HR in budgeting and control. This result seems to be in line with the results of the study conducted by Cohen and Karatzimaz (2011). Hence, in Pakistani organizations, the role of HR in budgeting has the greatest effect on the control function of the organization. Thus it implies that if HR departments get an opportunity to develop and implement budgets in their organizations, they would better have the opportunity to practice control on the performance of the organizations and hence, rectify any mediations from the targets set in the budgets.

Next to control is the strength of the relation that exists between HR in budgeting and communication and it was found to be 1.06. As has been discussed in the previous sections, an integral function within the organizations, communication, can be enhanced through the involvement of $\mathrm{HR}$ in the designing and implementation of the budgets.
Figure 1 also shows that performance evaluation is estimated to be slightly lower than communication in organizations. And the weakest regression weight estimate exists between role of HR in budgeting and motivation which is estimated to be 0.94 .

Hence, according to HR managers, involvement of HR department in budgeting process has the least to do with the motivational aspect among other three variables of interest in this study.

\section{Conclusion}

On the basis of the data collected from the HR managers in service based organizations of Pakistan, we presented some interesting statistics and we tested our model under the study. From the hypotheses generated for the model, several conclusions were extracted from the study are as follows.

Results showed that Pakistani organizations HR departments do not get involved during the drawing up and execution of the budgeting process and, hence, do not make proper use of budgeting as a means of tool for employee motivation, control, communication and performance evaluation.

On the other hand, it was found that HR managers consider the motivation, communication, performance evaluation and control uses of budgeting as important. More specifically, of these four functions the control function is rated as the most important one while the motivation function is ranked as the least important one.

The HR managers of different service based organizations in Pakistan were found to report that the participation of their department in the budgeting process leads to have a significant positive effect on different functions that are performed by their department. Among those functions, the highest affect was found to be on control and the least effect was found to be on the motivation.

\section{Limitations}

This research has certain limitations as well. First, the findings are based on the responses of HR managers from only service based organizations of Pakistan. A future research should be conducted in which this model should be tested in other sectors of Pakistan. It will help to compare the results among different industries in the country.

Second, a small sample size was taken for the study. Further research should be done with large sample size. Third, this study was carried out to investigate the role of involvement of HR department in budgeting on only four variables of interest. A future study must be undertaken investigating several other variables. 


\section{Future Research}

We believe that our findings reflect the current state of HR department and budgeting interaction in Pakistani companies subject to the limitations inherent in any study of this sort. A similar subsequent study would reveal the progress made in this aspect. It is a fact that the HR function remains at an early stage in Pakistan, which means that the responsibility for HR matters is gradually evolving. We believe that further research of the interaction between the budget procedures and the diffusion of the HR management philosophy inside the Pakistani organizations is needed. In-depth analysis through case studies could serve towards this goal.

\section{Acknowledgement}

Authors acknowledge the anonymous reviewers for their vaulabe inputs.

\section{Funding Information}

This researcj has not been funded by any authority.

\section{Author's Contributions}

Sibtain Kazmi: Is the main contributor of the paper. SAF Hasnu: Guided during the topic selection and methodology.

Raja Ahmed Jamil: Help in analysis and publicaiton process.

\section{Ethics}

Research is orignal and there are no ethical issues involved.

\section{References}

Anderson, R.E., 1993. Can stage-gate systems deliver the goods? Financial Executive, 9: 34-5.

Bacon, N. and R. Berry, 2005. Pursuing shareholder value: Implications for human resource management. CIMA Research Executive Summaries Series, Chartered Institute of Management Accountants, London.

Becker, S. and D. Green, Jr., 1962. Budgeting and Employee Behavior. J. Bus., 35: 392-402. DOI: $10.1086 / 294534$

Berry, R. and N. Bacon, 2002. Marshmallow land: Shareholder value management and human resource management. CIMA Research Update, Chartered Institute of Management Accountants, London, pp: 2-3.

Bisbe, J. and D. Otley, 2004. The effects of the interactive use of management control systems on product innovation. Accounting, Organizations Society, 29: 709-737.

DOI: $10.1016 /$ j.aos.2003.10.010
Blansfield, D., 2002. Comshare survey of top financial executives. Business Finance/Comshare Executive Research Group.

Bremser, W., 1988. Budgeting by Department and Functional Area. American Management Association, Watertown, MA.

Brownell, P., 1982. The role of accounting data in performance evaluation, budgetary participation and organizational effectiveness. J. Accounting Res., 20: 12-27. DOI: $10.2307 / 2490760$

Byrne, S. and F. Damon, 2008. To participate or not to participate? Voice and explanation effects on performance in a multi-period budget setting. British Accounting Rev., 40: 207-227. DOI: 10.1016/j.bar.2008.04.001

Chenhall, R.H. and P. Brownell, 1988. The effect of participative budgeting on job satisfaction and performance: Role ambiguity as an intervening variable. Accounting, Organizations Society, 13: 225-233. DOI: 10.1016/0361-3682(88)90001-3

Clinton, D.B. and J.E. Hunton, 2001. Linking participative budgeting congruence to organization performance. Behavioral Res. Accounting, 13: 127-41. DOI: $10.5539 /$ ibr.v3n4p181

Cohen, S. and S. Karatzimas, 2011. The role of the human resources department in budgeting: Evidence from Greece. J. Hum. Resource Costing Accounting, 15: 147-166. DOI: 10.1108/14013381111157355

Deci, E.L., 1971. The effects of externally mediated rewards on intrinsic motivation. J. Personality Social Psychol., 18: 105-15.

Deci, E.L., 1972. The effects of contingent and noncontingent rewards and controls on intrinsic motivation. Organiz. Behavior Hum. Performance, 8: 217-229. DOI: 10.1016/0030-5073(72)90047-5

Dermer, J., 1975. The interrelationship of intrinsic and extrinsic motivation. Academy Management J., 18: 125-129. DOI: $10.2307 / 255630$

Douglas, B.R., 1994. The budgeting process in a multinational firm. Multinational Bus. Rev., 2: 59-63.

Dunbar, R.L.M., 1971. Budgeting for control. Administrative Science Q., 16: 88-96. DOI: $10.2307 / 2391292$

Emmanuel, C., G. Kominis and S. Slapnicar, 2008. The effect of intrinsic and extrinsic rewards on the perceptions of middle level managers. CIMA Research Executive Summaries Series, Chartered Institute of Management Accountants, London.

Emsley, D., 2001. Budget-emphasis in performance evaluation and managers' job related tension: The moderating effect of information completeness. Brit. Accounting Rev., 33: 399-419. DOI: $10.1006 /$ bare.2001.0171

Fisher, J., 1995. Contingency-based research on management control systems: Categorization by levels of complexity. J. Accoun. Literature, 14: 24-53. 
Fisher, J., L.A. Maines, S.A. Peffer and G.B. Sprinkle, 2002. Using budgets for performance evaluation: effects of resource allocation and horizontal information asymmetry on budget proposals, budget slack and performance. Accounting Rev., 77: 847-65. DOI: $10.2308 /$ accr.2002.77.4.847

Guilding, C., D. Lamminmaki and C. Crury, 1998. Budgeting and standard costing practices in New Zealand and the United Kingdom. Int. J. Accounting, 33: 569-88.

DOI: 10.1016/S0020-7063(98)90013-9

Hansen, S. and W. van der Stede, 2004. Multiple facets of budgeting: An exploratory analysis. Management Accounting Res., 15: 415-39.

DOI: $10.1016 /$ j.mar.2004.08.001

Henri, J.F., 2006. Management control systems and strategy: A resource-based perspective. Accounting Organiz. Society, 31: 529-58.

DOI: $10.1016 /$ j.aos.2005.07.001

Hofstede, G.H., 1968. The game of budget control. Tavistock, London.

Hopwood, A.G., 1972. An empirical study of the role of accounting data in performance evaluation. Empirical Res. Accounting, 10: 156-182.

Joshi, P.L., J. Al-Mudhaki and M.G. Bremser, 2003. Corporate budget planning, control and performance evaluation in Bahrain. Managerial Auditing J., 18: 737-750. DOI: 10.1108/02686900310500505

Kaplan, R., 1998. Advanced Management Accounting, 3rd Edn., Prentice-Hall, Upper Saddle River, NJ.

Kenis, I., 1979. Effects of budgetary goal characteristics on managerial attitudes and performance. Accoun. Rev., 54: 707-721.

Kominis, G. and C. Emmanuel, 2007. The expectancyvalence theory revisited: Developing an extended model of managerial motivation. Management Accounting Res., 18: 49-750. DOI: $10.1016 /$ j.mar.2006.10.002

Kouhy, R., R. Vedd, T. Yoshikawa and J. Innes, 2009. Human resource policies, management accounting and organizational performance. J. Hum. Resource Costing Accoun., 13: 245-263.

DOI: 10.1108/14013380910995520

Lau, M.C. and C. Buckland, 2001. Budgeting-the role of trust and participation: A research note. Abacus, 37: 369-388. DOI: 10.1111/1467-6281.00092

Locke, E.A. and D.M. Schweiger, 1979. Participation in Decision Making: One More Look. In: Research in Organizational Behavior, Staw, B.M. (Ed.), JAI Press, Greenwich, CT.

Lyne, S.R., 1988. The role of the budget in medium and large UK companies and the relationship with budget pressure and participation. Accounting Bus. Rev., 18: 195-212.

DOI: $10.1080 / 00014788.1988 .9729367$
Marginson, D. and S. Ogden, 2005. Coping with ambiguity through the budget: the positive effects of budgetary targets on managers' budgeting behaviours. Accoun. Organiz. Society, 30: 435-456. DOI: $10.1016 /$ j.aos.2004.05.004

Merchant, K.A. and W. van der Stede, 2003. Management control systems: Performance measurement, evaluation and incentives. Pearson Education, Harlow.

Merchant, K.A., 1998. Modern Management Control Systems, Prentice-Hall, Upper Saddle River, NJ.

Nouri, H. and R.J. Parker, 1998. The relationship between budget participation and job performance: The roles of budget adequacy and organizational commitment. Accoun. Organiz. Society, 23: 467-483. DOI: 10.1016/S0361-3682(97)00036-6

Otley, D., 1978. Budget use and managerial performance. J. Account. Res., 16: 122-49. DOI: $10.2307 / 2490414$

Otley, D., 2006. Budgetary Control and Responsibility Accounting. In: Contemporary Issues in Accounting, Bhimani, A. (Ed.), Oxford University Press, Oxford.

Parker, L.D., 1978. Communication in the corporate budgetary system. Accounting Bus. Res., 8: 191-207. DOI: 10.1080/00014788.1978.9729122

Parker, R. and L. Kyj, 2006. Vertical information sharing in the budgeting process. Accounting Organiz. Society, 31: 27-46. DOI: $10.1016 /$ j.aos.2004.07.005

Reid, P., 2002. A critical evaluation of the effect of participation in budget target setting on motivation. Managerial Auditing J., 17: 122-129. DOI: $10.1108 / 02686900210419903$

Ronen, J. and J.L. Livingstone, 1975. An expectancy theory approach to the motivational impacts of budgets. Accounting Rev., 50: 671-685.

Searfoss, G.D. and R.M. Monczka, 1973. Perceived participation in the budget process and motivation to achieve the budget. Academy Management J., 16: 541-554. DOI: $10.2307 / 254689$

Simons, R., 1995. Levers of control: How managers use innovative control systems to drive strategic renewal. Harvard Business School Press, Boston, MA.

Stedry, A.C., 1967. Budget Control and Cost Behaviour. In: The Effects of Goal Difficulty on Performance: A Field, Stedry, A.C. and E. Kay (Eds.), Chicago: Markham Publishing Co.

Stiles, P. and S. Kulvisaechana, 2003. Human capital and performance: A literature review, Accounting for people taskforce, HMSO, London.

van der Stede, W.A., 2001. Measuring 'tight budgetary control'. Manage. Accoun. Res., 12: 119-137. DOI: 10.1006/mare.2000.0149 
Viswesvaran, C., 2011. Assessment of individual job perfromance: A review of the past century and a look ahead. Handbook Industrial Work Organizational Psychol.

Walker, K.B. and E.N. Johnson, 1999. The effects of a budget-based incentive compensation scheme on the budgeting behaviour of managers and subordinates. J. Management Accoun. Res., 11: 1-28.
Yuen, D.C., 2004. Goal characteristics, communication and reward systems and managerial propensity to create budgetary slack. Managerial Auditing J., 19: 517-32. DOI: 10.1108/02686900410530529 